
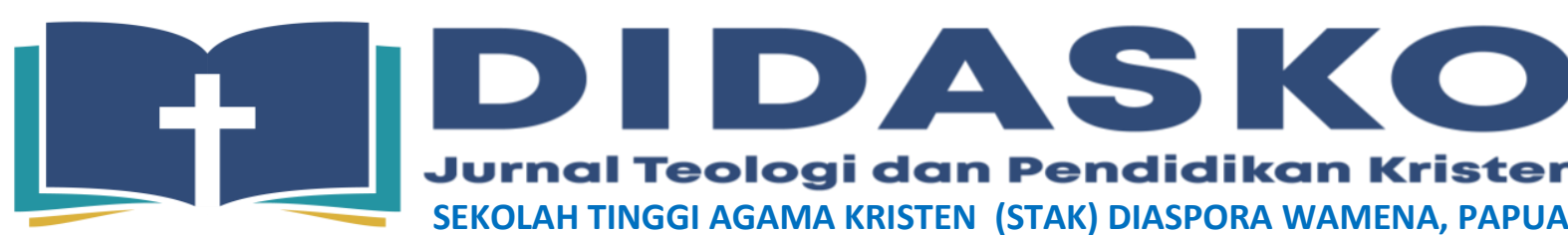

Jurnal Teologi dan Pendidikan Kristen

SEKOLAH TINGGI AGAMA KRISTEN (STAK) DIASPORA WAMENA, PAPUA

Volume 1 Nomor 1 (April 2021)

Web STAK DIASPORA Wamena: http://stakdiaspora.ac.id

Web DIDASKO: http://e-journal.stakdiaspora.ac.id/index.php/didasko/index

\title{
Peran Guru Pendidikan Agama Kristen dalam upaya Preventif Pornografi
}

\author{
Indrianto \\ Sekolah Tinggi Teologi Sangkakala, Salatiga \\ hendrianelka@gmail.com \\ Yonatan Alex Arifianto \\ Sekolah Tinggi Teologi Sangkakala, Salatiga \\ arifianto.alex@sttsangkakala.ac.id \\ Reni Triposa, \\ Sekolah Tinggi Teologi Sangkakala, Salatiga \\ renitriposa@sttsangkakala.ac.id
}

\begin{abstract}
Abstratc:
Pornography is an audio-visual product, image or writing that can design the sexual lust of someone who reads or watches it. According to the Christian view, pornography depicts sex in a sinful way, degrades human dignity, destroys marital commitments, and engenders lust and adultery. The cause of pornography addiction is due to internal and external factors. Pornography is bad for teenagers because it causes addiction, damages the brain, the desire to try and imitate, and initiates sexual acts. Through a descriptive qualitative approach, it can be concluded that the role of the teacher and Christian religious education is a teaching and learning process that is based on the Bible, centered on Christ, and depends on the power of the Holy Spirit to guide each person at all levels of faith growth. The role of the Christian Religious Education teacher is not just to provide guidance and teaching in the field of Christian Religious Education to students, but the goal that the teacher wants to achieve is to develop and foster faith, attitudes, and actions in accordance with the testimony in the Bible and applied to them. daily life of students. So that it can seek to prevent pornography in all aspects within the scope of education.
\end{abstract}

Keyword: The Role of Teachers, Christian Religious Education, Pornography, Christian Faith 


\begin{abstract}
Pornografi adalah sebuah produk audio-visual, gambar ataupun tulisan yang bisa merancang nafsu birahi seksual seseorang yang membaca ataupun menontonnya. Menurut pandangan Kristen pornografi menggambarkan seks dalam cara berdosa, merendahkan martabat manusia, menghancurkan komitmen perkawinan, dan menanamkan hawa nafsu dan perzinahan. Penyebab kecanduan pornografi karena ada faktor internal dan eksternal. Pornografi berdampak buruk bagi remaja karena menyebabkan kecanduan, merusak otak, keinginan untuk mencoba serta meniru, dan mulai melakukan tindakan seksual. Melalui pendekatan kualitatif deskriptif, maka dapat disimpulkan bahwa peran guru dan pendidikan agama Kristen adalah proses pengajaran dan pembelajaran yang berdasarkan Alkitab, berpusat pada Kristus, dan bergantung kepada kuasa Roh Kudus yang membimbing setiap pribadi pada semua tingkat pertumbuhan iman. Peran guru Pendidikan Agama Kristen bukan sekedar memberikan bimbingan dan pengajaran dalam bidang Pendidikan Agama Kristen kepada peserta didik, namun tujuan yang hendak di capai oleh guru yaitu untuk mengembangkan dan menumbuhkan iman, sikap, serta tindakan sesuai dengan kesaksian yang ada dalam Alkitab dan di aplikasikan kedalam kehidupan peserta didik seharihari. Sehingga dapat mengupayakan pencegahan pornografi dalam segala aspek dalam lingkup pendidikan.
\end{abstract}

Keyword: Peran Guru, Pendidikan Agama Kristen, Pornografi, Iman Kristen

\title{
PENDAHULUAN
}

Pada masa remaja dapat dikatakan bahwa seseorang telah mengalami perkembangan yang istimewa. Perkembangan spesifik yang dimaksud adalah masa peralihan dari anak ke dewasa, yang terjadi antara usia 10 hingga 21 tahun (Diananda 2019). Remaja tidak akan puas hanya dengan melihat benda dari luar. Tetapi mulailah mencari jarak untuk menemukan jawaban mengapa aksi itu harus dilakukan atau mengapa aksi itu dibentuk seperti itu (Mulyono 1986, 915). Di masa peralihan ini bisa dilihat bahwa rasa ingin tahu seorang remaja begitu besar sehingga mereka tidak puas hanya mengetahui sesuatu dari luarnya saja melainkan mereka selalu ingin memperjelas atas apa yang mereka ingin tahu. Di lingkungan para siswa Sekolah Menengah Atas (SMA) akan di perhadapkan dengan masa peralihan di mana intelektualitas setiap siswa mengalami perkembangan terus-menerus, rasa ingin tahu siswa dan siswi cenderung tinggi. Pornografi itu merupakan sebutan dari bahasa Yunani, yaitu Pornografi. Penyebutan tersebut mengandung penulisan ataupun illustrasi mengenai wanita sundal (Soebagijo 2008, 25). Maka dengan demikian dapat di artikan sebagai peransang birahi seksual.

Menurut Mohammad, pornografi pada umunya merupakan sebuah produk audio-visual, gambar ataupun tulisan yang bisa merancang nafsu birahi seksual seseorang yang membaca ataupun menontonnya (Widarti 2008b). Sedangkan menurut definisi "Kamus Besar Bahasa Indonesia", pornografi adalah penggambaran perilaku pornografi yang sengaja dirancang untuk membangkitkan hasrat seksual melalui gambar atau tulisan, atau dengan membaca atau persetubuhan (Soebagijo 2008, 27). Seks mengacu pada gender. Segala sesuatu yang berkaitan dengan gender disebut seks. Seks melibatkan banyak aspek, termasuk aspek biologis, psikologis, sosial dan budaya (Sebayang, Gultom, and Sidabutar 2018, 4). 
Berdasarkan uraian di atas, penulis menarik kesimpulan yaitu pornografi ini merupakan media elektronik maupun cetak yang di fokuskan dalam gambar maupun tayangan berbentuk video atau adegan yang dilakukan tanpa busana, dan tayangan tersebut dapat membangkitkan nafsu berahi seseorang bagi yang menontonnya.

\section{METODE}

Jenis penelitian artikel ini adalah studi pustaka dengan menggunakan metode deskriptif dan kualitatif (Zaluchu 2020). Penulis melakukan kajian mengenai literatur lalu menjelaskan dengan satu kemerosotan moral moral di ranah pornografi. Bukan hanya memakai Alkitab untuk dijadikan literatur utama, namun juga menggunakan buku dan literatur lainnya yang lebih relevan berkaitan dengan tema sesuai patokan literatur ulasan yang di inginkan oleh Denney (Denney and Tewksbury 2013). Penulis juga menggunakan berbagai literatur tumpuan yang bisa membantu untuk melengkapi artikel tersebut yang diharapkan masih bisa menjadi pendukung artikel ini. Selain itu, penulis menggunakan dan merujuk dari berbagai sumber jurnal dalam mendeskripsikan tujuan penulisan tentang peran guru dalam preventif pornografi ini.

\section{PEMBAHASAN Hakikat Pornografi}

Pornographia itu adalah sebutan dari Yunani, yaitu Pornografi. Penyebutan tersebut mengandung penulisan ataupun illustrasi mengenai perempuan sundal (Soebagijo 2008, 25). Maka dengan sebutan lain bisa diartikan sebagai peransang berahi seksual. Menurut Mohammad, pornografi pada umunya merupakan sebuah produk audio-visual, gambar ataupun tulisan yang bisa merancang nafsu berahi seksual seseorang yang membaca ataupun menontonnya (Widarti 2008a). Sedangkan menurut definisi "Kamus Besar Bahasa Indonesia" mendefinisikan Pornographia sebagai pencitraan akhlak secara seksual melalui gambaran ataupun sebuah penulisan yang dapat membangunkan keinginan untuk berhubungan seksual, ataupun materi bacaan yang memang di sengaja dan dibuat untuk memberikan dorongan berhubungan seksual (Soebagijo 2008, 27). Seks yang berarti jenis kelamin menjadi tujuan dari konten pornografi. Tetapi segala sesuatu yang berkenaan dengan gender disebut seks. Seks melibatkan banyak aspek, termasuk aspek biologis, psikologis, sosial dan budaya (Sebayang, Gultom, and Sidabutar 2018, 4).

Jika dilihat dari pengertian pornografi berdasarkan Undang-Undang Nomor 44 Tahun 2008 menjelaskan bahwa yang dimaksud dengan pornografi adalah gambar, sketsa, ilustrasi, foto, teks, suara, suara, gambar bergerak, animasi, kartun, dialog, gerak tubuh atau bentuk komunikasi lain melalui berbagai bentuk media komunikasi atau pertunjukan yang dilakukan di tempat umum yang mengandung eksploitasi atau eksploitasi seksual yang melanggar norma etika umum di masyarakat (KEMENTERIAN, ANAK, and INDONESIA 2016). Berdasarkan hasil identifikasi Komisi Meese yang diketuai oleh Edwin Meese yang menjabat sebagai Jaksa Agung Amerika, pornografi yang berkembang di masyarakat dapat dibagi menjadi lima jenis pornografi (Soebagijo 2008, 36). Satu, Sexually Violent material, merupakan bahan pornografi yang mengandung adegan seksual dan melibatkan aksi kekerasan. Dua, Materi non-kekerasan yang menggambarkan degradasi, dominasi, subordinasi, atau penghinaan. Materi pornografi ini mengandung unsur yang merendahkan atau melecehkan perempuan. Contohnya berhubungan seks oral yaitu satu perempuan dengan banyak laki-laki. Tiga, Nonviolent and nondegrading 
material merupakan pornografi dengan tampilan pasangan yang sedang melangsungkan berhubungan badan tanpa adanya sebuah paksaan. Empat ketelanjangan, merupakan bahan persetubuhan yang hanya memperlihatkan bentuk tubuh tanpa busana atau ketelanjangan, salah satunya majalah playboy termasuk ke dalam kategori ini. Lima, Child Pornography merupakan materi pornografi yang memperlihatkan anak atau remaja di bawah umur untuk menjadi model dalam adegan seks tersebut (Soebagijo 2008, 36-37).

\section{Pornografi Menurut Pandangan Kristen}

Berbicara mengenai pornografi memang pada hakikatnya tidak bisa dipisahkan dari sudut pandang norma berhubugan badan. Permasalahan pada pornografi ialah perkara yang berkaitan dengan seksual ataupun lebih tepatnya yaitu sebuah pelanggaran dalam seksual. Maka dari itu yang menjadi tolak ukur dalam menelaah persoalan ini yaitu pemahaman Alkitabiah mengenai seks(Irawan 2020). Bisa dilihat poin-poin di bawah ini yang menyebutkan tanggapan Alkitabiah mengenai Pornografi.

\section{Pornografi Menggambarkan Seks dalam Cara Berdosa}

Dalam kitab (Kej 1:27) menyebutkan bahwa manusia itu diciptakan oleh Allah yaitu pria dan wanita berdasarkan rupa Allah, selanjutnya pada ayat 31 Allah melihat semuanya itu baik. Oleh karena itu, sebagai anugerah dari Allah, seks secara keseluruhan adalah hal yang baik. Tetapi pornografi memisahkan seks dari kejeniusan manusia, dan percaya bahwa citra Tuhan terpisah dari potret. Materi pornografi apapun sebenarnya menunjukkan bahwa perilaku seksual adalah dosa, dan tidak mencerminkan moralitas ketuhanan manusia.

\section{Pornografi Merendahkan Martabat Manusia}

Perbedaan gender dipahami sebagai perbedaan bahwa Allah memiliki nilai yang sama untuk saling melengkapi. Pada saat yang sama, seks adalah kodrat manusia yang diciptakan Tuhan menurut keberadaan seksual (Kejadian 1:27). Allah memang merancang kehidupan seks dalam hubungan (persekutuan) yang melibatkan semua aspek kehidupan. Namun, pornografi sebenarnya mengukur seks hanya dalam kaitannya dengan hasrat seksual dan tidak berhubungan dengan aspek-aspek lain dari keberadaan manusia. Dengan cara ini, seks hanya akan dipahami sebagai kejahatan berdosa yang tidak sesuai dengan akhlak Allah (Soebagijo 2008, 10-11).

\section{Pornografi Menghancurkan Komitmen Perkawinan}

Allah membuat sebuah ikatan pernikahan untuk manusia supaya berkomitmen seumur hidupnya (Danes and Danes 2000, 52). Selain itu dalam kitab (Kej. 2:22-25) Allah menciptakan perjanjian dalam sebuah ikatan perkawinan, dan dalam kitab (Ibr. 13:4) menyuarakan supaya sebuah perkawinan itu suci dan dihormati oleh manusia. Karena dalam sebuah perkawinan membutuhkan sebuah keseriusan dan bersedia memikul tanggung jawab dalam rumah tangga.

\section{Pornografi Menanamkan Hawa Nafsu dan Perzinahan}

Persundalan itu adalah sebuah perbuatan yang berhubungan badan dari orang yang tidak memiliki ikatan pernikahan dan diperbuat sebelum menikah, ini merupakan seksual yang dilakukan tanpa ada pernikahan. Kegiatan berhubungan badan yang ditampilkan di dalam tayangan pornografi merupakan persundalan dan memang dibuat agar mendorong individu untuk berhubungan seksual. Padahal dalam kitab (Kel. 20: 14) Allah sangat menentang keras mengenai perzinahan, melarang mengenai persundalan diperuntukkan kepada laki-laki ataupun perempuan agar menjaga kekudusan sebuah ikatan pernikahan. Selain itu dalam kitab (Mat. 5-7) Tuhan Yesus juga menyumpahi perbuatan persundalan serta menuding semua yang 
berhubungan dengan perzinahan. Ketika seseorang mencari kepuasan dengan cara melihat tayangan ataupun gambar-gambar pornografi, meskipun orang tersebut tidak ikut terlibat dalam adegan tayangan pornografi, maka hal tersebut juga termasuk ke dalam rupa dosa yaitu keinginan yang mengarah kepada dosa. Karena di dalam kitab Matius 5: 27-30; Tuhan Yesus menasehati sesungguhnya keinginan daging atau keinginan yang bertentangan dengan Firman Allah merupakan sebuah pelanggaran atau dosa perzinahan(Irawan 2020).

\section{Penyebab kecanduan Pornografi}

Jika seorang individu sering menonton pornografi, tentu ada penyebab atau faktor yang mendukung kebiasaan tersebut. Salah satu penyebab menonton pornografi dikarenakan oleh aspek suasana, tetapi suasana yang sangat berdampak merupakan suasana keluarga. Secara umum ada dua penyebab yang mempengaruhi seorang individu menonton tayangan pornografi, adapun faktor tersebut yaitu faktor internal dan eksternal. Menurut Nur Daniati, Faktor dari dalam merupakan keinginan untuk mengetahui, minat melihat konten pornografi di Internet, dan kebutuhan seksual yang kuat. Pada saat yang sama, faktor dari luar meliputi metode pengasuhan, pengaruh lingkungan, pengaruh teman sebaya, dan teknologi (E. Novita 2018). Supaya bisa memahami lebih jelas, maka penulis menjelaskan sedikit mengenai penyebab atau faktor-faktor menonton pornografi yaitu:s

Pertama, Diri sendiri, rasa ingin mengetahui atau penasaran dari seorang individu mendorong individu tersebut untuk menggunakan media pornografi secara aktif. Kedua, Kecanggihan teknologi, kemajuan teknologi di masa sekarang memicu individu untuk mengakses atau mencari tayangan pornografi dengan mudah. Ketiga, Teman sebaya, seorang individu yang menjadi pelanggan aktif tayangan pornografi tidak lepas dari teman sebaya yang juga aktif dengan mengakses tayangan pornografi, sehingga tayangan tersebut bisa ditonton juga oleh orang lain. Keempat, Keluarga, kurangnya pendidikan dan pengawasan dalam keluarga serta terbatasnya komunikasi mengenai pendidikan seksualitas menyebabkan individu tersebut mencari pengetahuan sendiri mengenai seksualitas. Kelima, Sarana dan prasarana, tidak tersedia atau kurangnya tempat-tempat yang bisa menyalurkan hobi dan bakat dari individu tersebut untuk meluangkan waktu kosong, supaya pikirannya teralihkan dengan kegiatan yang positif (Danes and Danes 2000, 41).

\section{Dampak Pornografi}

Tayangan pornografi dapat menimbulkan dampak buruk bagi remaja yang menjadi pelanggan aktif tayangan pornografi. Dampak buruk tersebut ialah ketagihan, kerusakan otak, kehendak untuk bereksperimen serta mencontoh, dan mulai berbuat pelecehan seksual. Konten pornografi yang muncul di media sosial dan terlihat secara tidak sengaja maka akan muncul rasa penasaran yang mendorong remaja untuk menyaksikan konten pornografi lainya (M. Novita 2019). Menonton tayangan pornografi juga berpengaruh kepada otak. Otak manusia adalah anggota tubuh yang paling penting untuk manusia, komponen otak yang sangat spesial dinamakan dengan Pre Frontal Cortex (PFC) (Kastilong 2019).

Kerusakan terhadap otak Pre Frontal Cortex efek ketagihan tayangan pornografi Secara ilmiah, dopamin akan dialirkan melalui sistem limbik ke Pre Frontal Cortex. Individu yang ketagihan terhadap pornografi akan mengalirkan cairan dopamin melampaui batas. Kemudian akan membanjiri Pre Frontal Cortex dan otak Pre Frontal Cortex akhirnya tidak berfungsi dengan baik disebabkan terendam oleh cairan dopamin. Selain itu menurunnya fungsi otak Pre Frontal Cortex, lama kelamaan individu ini akan melakukan onani atau masturbasi, oral seks, hubungan seks di luar nikah, berganti pasangan, perkawinan dianggap tidak penting, pasangan dianggap sebagai objek seksual murni, cenderung merendahkan lawan jenis, dan hasrat seksualnya tidak 
normal (kasar dan semena-mena). Donald Hilton Jr., seorang ahli bedah otak, mengatakan jika foto tersebut menggunakan peralatan magnetic resonance imaging, maka otak yang rusak akibat pornografi memiliki hasil yang sama dengan otak akibat kecelakaan tersebut. Donald Hilton Jr. juga mengatakan bahwa efek narkoba hanya merusak tiga bagian otak, sedangkan individu yang kecanduan pornografi mengalami kerusakan otak di lima bagian. Ini membuktikan bahwa pornografi merusak otak (ORG 2015). Bisa dilihat dari pernyataan para ahli bahwa pornografi memang merusak otak dan mempengaruhi perilaku seorang individu yang kecanduan pornografi.

Kecanduan pornografi bukan hanya menyebabkan gangguan pada otak, tetapi juga menyebabkan ganguan jiwa apalagi jika sudah melewati batas (Yusnadewi 2013, 51). Jika seorang siswa sering menonton tayangan pornografi maka siswa ini akan kecanduan dengan video dan tayangan tersebut. Sehingga siswa ini akan lebih banyak meluangkan waktunya untuk mengakses dan menonton video pornografi dari pada meluangkan waktunya untuk belajar.

Tayangan video pornografi akan mempengaruhi otak dan pikiran, sehingga anak yang menonton video pornografi akan sering terbayang dan mengingat setiap adengan yang telah dilihat. Maka tayangan itu akan terekam dalam memori anak, dampaknya tayangan tersebut akan sulit dihapus dari memori anak bahkan membutuhkan waktu yang lama (Solikhin 2018, 182). Ketika seorang siswa yang sering membayangkan adegan pornografi dalam pikirannya maka akan memunculkan keinginan untuk mencoba atau mempraktekan adegan pornografi. Pornografi cenderung mengarahkan penontonnya untuk beranggapan bahwa perilaku apapun yang dianggap aneh dan menjijikan bagi sebagian orang merupakan hal yang menyenangkan, nikmat, dan cukup normal untuk dilakukan. Hal ini dilakukan penonton pornografi di balik pintu kamar secara diam-diam dan mengalami perasaan yang menyenangkan (Auer 2002, 90).

Otak adalah bagian terpenting dari tubuh manusia, dan bagian paling khusus dari otak disebut Pre Frontal Cortex (PFC) (Fatin Hafizah and Shahar 2018). Otak tersebut terletak di bagian depan kepala manusia. Menurut peneliti otak Jordan Grafman (Jordan Grafman), jenis otak tersebut hanya ada pada manusia. Bagian otak tersebut yang membedakan manusia dari hewan. Otak ini memang diciptakan istimewa oleh Tuhan agar manusia memiliki akhlak dan dapat membedakan yang baik dari yang buruk. Otak Pre Frontal Cortex ini berfungsi sebagai ketua untuk mengarahkan, berkonsentrasi, untuk memahami benar dan salah, pengendalian diri, tunda kepuasan, berpikir kritis dan rencanakan masa depan. Otak tersebut merupakan sentral penilaian pengambilan kesimpulan, karena otak Pre Frontal Cortex maka otak inilah yang sangat berpengaruh dalam membentuk perilaku sosial dan karakter seseorang. Tapi sangat disayangkan otak Pre Frontal Cortex ini merupakan bagian yang paling mudah rusak yang di sebabkan oleh hantaman fisik, zat murni (zat kimia) seperti narkoba, psikotropika, dan zat adiktif (NAPZA), dan pornografi yang dikenal dengan narkoba melalui mata (Narkolema).

Jika tidak segera ditangani, orang tersebut akan menjadi pengguna pornografi dan mengalami kerusakan otak di korteks prefrontal, yang pada awalnya akan kehilangan konsentrasi, mengurangi kepekaan benar dan salah, dan mengurangi kemampuan untuk mengambil keputusan. Selain itu menurunnya fungsi otak Pre Frontal Cortex, lama kelamaan individu ini akan melakukan onani atau masturbasi, oral seks, hubungan seks di luar nikah, berganti pasangan seksual, perkawinan dianggap tidak penting, pasangan dianggap sebagai objek seksual murni, cenderung merendahkan lawan jenis, dan hasrat seksualnya juga tidak normal (kasar dan semena-mena) bahkan berani memperkosa (ORG 2015). Bisa dilihat dari pernyataan para ahli bahwa pornografi memang merusak otak dan mempengaruhi perilaku seorang individu yang kecanduan pornografi. 
Kecanduan pornografi bukan hanya menyebabkan gangguan pada otak, tetapi juga menyebabkan ganguan jiwa apalagi jika sudah melewati batas(Yusnadewi 2013, 51). Jika seorang siswa sering menonton tayangan pornografi maka siswa ini akan kecanduan dengan video dan tayangan tersebut. Sehingga siswa ini akan lebih banyak meluangkan waktunya untuk mengakses dan menonton video pornografi dari pada meluangkan waktunya untuk belajar. Hal ini juga di dukung dengan mudahnya akses untuk melihat tayangan pornografi membuat peluang bagi siswa untuk melihat tayangan pornografi.

Selain itu siswa ini berpotensi merusak moral atau etika dari dirinya sendiri akibat pengaruh video pornografi. Bisa dilihat dari segi etika atau moral, Menurut Prof. Dr. N. Driyarkara, kesadaran terhadap moral merupakan kesadaran yang berkaitan tentang diri manusia itu sendiri, ketika manusia itu bisa melihat diri sendiri yang sedang berhadapan dengan sesuatu baik dan yang buruk (Driyakarya 1966, 13-15). Ketika seorang siswa krisis akan moral, maka siswa tersebut susah membedakan hal yang sopan dan baik untuk dilakukan. Terlibat dalam pornografi akan menghancurkan norma-norma masyarakat, menghancurkan keharmonisan hidup, keluarga, dan seluruh masyarakat, serta menghancurkan nilai-nilai luhur dalam kehidupan manusia, seperti nilai cinta, kesetiaan, cinta, keadilan dan keadilan. jujur. Nilai-nilai tersebut sangat dibutuhkan oleh masyarakat, sehingga hubungan yang sehat dapat terjalin dan terjamin dalam masyarakat (Diananda 2019). Siswa yang sering menonton tayangan pornografi, akan mempengaruhi sikapnya dalam kehidupan kesehariannya termasuk sikap di sekolah.

\section{Potensi celah yang mengancam anak-anak}

Bisnis pornografi menjadi salah satu bisnis yang populer dan berkembang, ini dikarenakan bisnis pornografi memberikan keuntungan yang besar bagi industri film dewasa. Bahkan dari sumber NBC News, menyebutkan bahwa nilai bisnis pornografi ini mencapai 12 milyar dolar di Amerika Serikat, tetapi untuk bisnis pornografi secara global bisa mencapai 97 milyar (Syafriadi 2020). Hal inilah yang menyebabkan video atau tayangan pornografi berhamburan di internet dengan mudah di akses dan didownload dengan menggunakan web dan aplikasi tertentu.

Padahal sekarang, pemerintah sudah membuat undang-undang mengenai pornografi. Perilaku pornografi dan pornografi adalah perilaku yang memang berdampak negatif pada perilaku generasi muda. Oleh karena itu, pornografi dan pornografi digolongkan sebagai tindak pidana (Djubaedah 2011,3). Undang-undang tersebut sudah memuat lengkap semua yang berkenaan dengan hal-hal yang terkait dengan pornografi, Undang-undang tersebut berisi tentang ketentuan umum, larangan dan larangan, perlindungan anak, pencegahan, penyidikan, penuntutan dan pemeriksaan di pengadilan, ketentuan pemusnahan dan pidana. Berdasarkan data dari Biro Pusat Statistik (BPS), menjelaskan ada 132 juta orang Indonesia yang menggunakan internet. Data yang ditemukan mencapai 12,5 juta orang Indonesia dalam mengakses internet pada usia 15-19 tahun. Setelah itu menurut pemantauan Komisi Perlindungan Anak Indonesia (KPAI) kepada 4.500 siswa Sekolah Menengah Pertama (SMP) dan Sekolah Menengah Atas (SMA) pada 12 kota menemukan bahwa tingkat pengaksesan konten pornografi mencapai 97\% (Miris! Indonesia Jadi Juara Negara Pengakses Situs Konten Dewasa 2018).

Kemudian, berdasarkan hasil studi Komisi Kependudukan dan Keluarga Berencana Nasional (BKKBN), ditemukan data bahwa meski belum menikah, hampir 80\% remaja masih berhubungan seks dengan lawan jenis, setelah itu para remaja yang telah hamil di luar nikah, akan melangsungkan pernikahan untuk menutupi aibnya. Berdasarkan hasil kajian yang ditemukan oleh Badan Kependudukan dan Keluarga Berencana Nasional (BKKBN) di tahun 2010 menyebutkan bahwa pada umumnya dari 100 remaja yang berada di daerah Jabodetabek, 54 persen sudah melakukan sexsual sebelum menikah, Surabaya, Bandung, dan Medan mencapai 52 persen (Lestari, Hanum, and Nopianti 2016). Selain itu berdasarkan peninjauan 
dari Komisi Nasional (Komnas) perlindungan anak yang ada di 33 Provinsi pada bulan Januari hingga Juni 2018 menyatakan 97\% remaja Sekolah Menengah Pertama (SMP) dan Sekolah Menengah Atas (SMA) telah menonton film pornografi, 93,7\% remaja sudah pernah melakukan berciuman, memegang-megang alat vital (genital stimulation), berhubungan badan dengan menggunakan mulut (oral sex) dan 62,7\% remaja SMP mengaku sudah tidak virgin lagi, sedangkan 21,2\% remaja mengaku bahwa sudah pernah melakukan aborsi (Djubaedah 2011, 4).

Survei yang dilakukan oleh Komisi Kependudukan dan Keluarga Berencana Nasional (BKKBN) tentang kehamilan dan pernikahan dini di Kalimantan Tengah pada tahun 2017 menunjukkan bahwa untuk setiap seribu penduduk usia 15-19 tahun, sekitar 72,92\% remaja hamil dan melahirkan (K 2017). Meski data Badan Pusat Statistik (BPS) mengenai jumlah kawin dini di Kota Puruk Cahu, remaja yang menikah berusia 20 tahun ke bawah, sedangkan UKP berusia antara 15-19 tahun dan mencapai 58,38 di tahun 2014(Sipayung and Heriteluna 2017).

\section{Ciri-ciri Kecanduan Pornografi}

Saat ini umat manusia sedang menghadapi fenomena kehancuran yang merupakan bagian dari globalisasi. Dapat dijelaskan bahwa kehancuran merupakan perubahan yang mendasar atau fundamental, yaitu perkembangan teknologi yang mengarah pada kesenjangan kehidupan manusia. Pakar dan pengamat media menyimpulkan bahwa abad ke-21 adalah era teknologi dan informasi, dan umat manusia telah memasuki dunia tanpa batas. Ciri khas era ini adalah informasi yang disebarluaskan melalui media massa akan sangat menentukan arah pembangunan masyarakat (Fikri 2019). Selain untuk mengakses informasi dengan mudah dan cepat, dunia maya juga memberikan dampak negatif bagi siswa. Tersedia berbagai materi berdampak buruk yang tersebar di dunia internet. Seperti kebencian, rasisme, pornografi, kejahatan, kekerasan, dan tindakan kejehatan lainnya. Internet pada mulanya di gunakan hanya oleh instansi tertentu, tetapi sekarang sudah di gunakan oleh masyarakat luas. Mengakses internet pada masa sekarang bukan hanya mudah tetapi juga murah dan terjangkau (Djubaedah 2011,7).

Ketagihan terhadap pornografi adalah perilaku berulang dalam melihat hal-hal yang merangsang hasrat seksual dan kehilangan kendali diri untuk mencegah hasrat seksual. Seorang remaja yang sudah kecanduan pornografi akan merasa cemas dan takut rahasianya terbongkar, pikirannya kacau karena selalu tertarik ingin mencari hal-hal yang berbau porno, susah berkonsentrasi terhadap keluarga ataupun teman-teman sebayanya, mudah marah serta tersinggung, dan pelupa karena sulit berkonsentrasi (Djubaedah 2011, 12). Ketika seorang remaja yang sering menonton tayangan pornografi sehingga remaja tersebut menjadi pelanggan aktif atau kecanduan pornografi, maka akan mempunyai ciri-ciri yang ditimbulkan akibat dari kecanduan menonton tayangan pornografi. Ciri-ciri kecanduan tayangan pornografi yang harus di ketahui antara lain: Ketika seseorang memintanya untuk berkomunikasi, dia biasanya tampak gugup dan menghindari kontak mata secara langsung. Semangat untuk beraktivitas tidak ada, pencapaian belajar merosot. Menjadi pemalas, kurang minat untuk melatih diri dalam pelajaran, dan tidak mau bersosialisasi serta susah untuk berkonsentrasi. Terikat dengan gadgetnya. Lebih senang menyendiri, terutama di kamarnya sendiri (Sardjito 2019).

\section{Pengertian dan Tujuan Pendidikan Agama Kristen}

Pendidikan agama Kristen merupakan proses pengajaran berdasarkan Alkitab dan berpusat pada Kristus, yang bersandar pada kuasa Roh Kudus untuk membimbing orang-orang dari semua tingkat iman dan pertumbuhan. Pengertian tersebut menjelaskan bahwa pengajaran Pendidikan

Agama Kristen memang di khususkan untuk segala usia di tingkatan yang berbeda-beda dalam pertumbuhan rohani setiap indvidu. Pendidikan Agama Kristen adalah sebuah pengajaran yang dilakukan untuk mengajarkan setiap individu yang beragama Kristen untuk mengenal siapa 
Tuhan Yesus itu dengan pondasi iman yang sesungguhnya berlandasan Alkitabiah, karena Alkitab sebagai dasar fondasi kerohanian yang tepat bagi orang percaya (Arifianto 2020). Terlebih Firman Allah dapat membawa orang percaya menjadi terang (Waruwu, Arifianto, and Suseno 2020), bagi dunia yang saat ini berada pada akhir zaman. Berdasarkan pandangan para ahli, E.G. Homrighausen berpendapat bahwa Pendidikan Agama Kristen berpusat kepada persekutuan orang-orang yang terpanggil untuk menjadi umat Tuhan. Pada hakekatnya dasardasar ini terdapat di dalam Alkitab Perjanjian Lama yang menjadi sejarah suci zaman kuno. Pendidikan agama kristen dimulai ketika Abraham menjadi nenek moyang dari pengikut pilihan Tuhan dan disebut sebagai pribadi pilihan Tuhan, meskipun pendidikan agama kristen juga mengandalkan Tuhan sendiri, karena dia menjadi pembelajar bagi bangsanya (Homrinhausen 2013, 12). Berdasarkan sudut pandang Warner C. Graedorf bahwa Pendidikan Agama Kristen merupakan metode pembelajaran dan pengajaran yang berlandaskan kepada Alkitabiah, menjadikan Yesus Kristus sebagai pusat pengajaran, dan berserah terhadap Roh Kudus, untuk mengarahkan setiap individu untuk semua tingkatan perkembangan iman kerohanian melewati pembimbingan modern yang mengarah kepada pengenalan, untuk mengalami rencana, kehendak Allah melewati Kristus dalam semua bagian kehidupan, dan berikan mereka pelayanan yang efektif, dengan fokus pada perintah yang mendewasakan murid dan berpaut terhadap Kristus Guru yang Agung. Serta kekuatan kuasa Roh Kudus untuk membimbing semuanya kepada kebenaran Tuhan, supaya orang yang dipimpinnya dapat terhindar dari rencana yang menjerumuskan (Arifianto and sumiwi Rachmani 2020), maupun dari kecemaran dosa.

Secara umum pendidikan agama pada dasarnya merupakan sebuah usaha untuk mengembangkan kemampuan dan kepribadian individu baik itu di sekolah internal dan eksternal yang bisa bertahan seumur hidup(Kusrahmadi 2007). Oleh sebab itu, pendidikan agama merupakan sebuah metode pendidikan nasional yang mengatur bahwa kurikulum dan isinya memang harus mencantumkan pendidikan agama, pancasila, dan kewarganegaraan (UU No. 2 Tahun 1989). Pendidikan agama menurut Sunarso didasarkan pada keyakinan yang dianut oleh peserta didik untuk memperkuat keyakinan dan pengabdiannya kepada Tuhan Yang Maha Esa, keyakinan tersebut terkait dengan kelompok agama lain dalam masyarakat untuk menghormati dan mewujudkan agama orang lain, syarat persatuan bangsa adalah terkait. Sedangkan tujuan dari Pendidikan Agama Kristen secara global yaitu supaya murid yang dibimbing sebagai generasi penerus bisa menghayati dan mengerti sebagai pengikut Allah yang mempunyai tugas penting buat jadi berkat bagi dunia, negara, dan bangsa Indonesia. Selain itu terdapat juga tujuan Pendidikan Agama Kristen secara spesifik yaitu usaha untuk mengarahkan dan membangkitkan peserta didik agar berkembang untuk menggapai kepribadian yang utuh mencerminkan sebagai gambar Allah yang mempunyai sifat kasih dan ketaatan pada Tuhan, mempunyai kecerdasan, keterampilan, berbudi pekerti yg luhur, kesadaran dan memelihara lingkungan hidup, serta ikut bertanggung jawab pada pembangunan masyarakat, berbangsa, dan bernegara (Paul Lilik Kristianto 2006, 5).

Selain itu penulis juga mencantumkan tujuan pendidikan agama kristen dari pendapat para ahli. Para ahli berpendapat bahwa Pendidikan Agama Kristen memberi pemahaman berdasarkan tujuan masing-masing dalam menafsirkan pendidikan. Menurut Thomas H. Groome tujuan Pendidikan Agama Kristen merupakan penuntun orang-orang untuk ke luar mengarah kepada Kerajaan Allah di dalam Yesus Kristus (Groome 2017, 49). Bisa diartikan bahwa melalui pengajaran tentang Allah bisa mengubah hati peserta didik dalam merangkai kehidupan menjadi lebih baik seperti kata- kata dan perbuatan. Sedangkan menurut Miler, tujuan Pendidikan Agama Kristen merupakan pengantar pelajar sehingga bisa mengalami pengalaman yang benar bersama Allah, Bapa Tuhan Yesus Kristus, tujuan yang dimaksud supaya bisa menjadikan peserta didik sebagai murid sejati (Pazmino 2012, 691).

\section{Peran Guru Pendidikan Agama Kristen}


Guru merupakan orang yang mendapat kepercayaan dari Tuhan untuk melaksanakan pengajaran dan pendidikan berdasarkan dengan karunia yang telah diberikan kepadanya. Guru adalah salah satu unsur-unsur manusia dalam proses pengajaran dan pembelajaran di sekolah, yang berpartisipasi dalam upaya untuk menetapkan potensi sumber daya manusia di bidang pembangunan (Sardiman 2007, 125). Komponen manusia yang dimaksud penulis adalah manusia yang menjadi sumber dan pelaku dalam pendidikan yang meraih semua aspek perkembangan dan kehidupan adalah aspek fisik, spiritual dan pribadi (Prayitno 2009, 30). Selain itu, guru juga sebagai manusia dalam pendidikan sekolah. Karena guru adalah sosok sumber manusia yang menempati posisi dan memainkan peran penting dalam proses pendidikan (Djamarah 2005, 1). Atas dasar Undang-Undang Republik Indonesia No. 14 tahun 2005 tentang Pembicara dan Guru, yaitu guru sebagai pendidik profesional, dengan tugas utama mendidik, mengajar, bimbingan, manajemen, pelatihan, evaluasi dan evaluasi masa kanak-kanak awal Siswa pendidikan, pendidikan dasar dan pendidikan menengah.

Peran guru pendidikan Kristen tidak hanya memberikan saran dan pengajaran di bidang Kekristenan kepada siswa, tujuan yang ingin dicapai oleh guru harus mengembangkan dan mengembangkan iman, sikap dan tindakan sesuai dengan kesaksian Alkitab dan diterapkan pada kehidupan siswa sehari-hari (Intarti 2016). Selain itu guru juga berperan sebagai demonstrator yang selalu mengembangkan dan meningkatkan kemampuan yang dimilikinya untuk menguasai setiap materi dan bahan pelajaran.

\section{Upaya Pencegahan Pornografi}

Upaya pencegahan pornografi bisa di mulai dari orang tua dalam mendidik remaja. Orang tua harus meluangkan waktu sebanyak-banyaknya dengan remaja supaya mereka merasa di perhatikan. Mengajak remaja ngobrol mengenai apa pun mengenai dirinya, dan mengawasi kegiatan remaja serta menanamkan ajaran agama yang kuat (M. Novita 2019). Dalam upaya pencegahan pornografi agar remaja atau anak-anak tidak terpapar tayangan pornografi kemudian menjadi pecandu pornografi, harus ada hal-hal yang dilakukan oleh individu supaya menyibukkan diri dengan kegiatan yang positif, seperti berolahraga dan menghindari tayangan atau media sosial yang mengundang nafsu berahi (Haidar and Apsari 2020). Selain itu, bergaullah dengan kelompok ataupun komunitas yang membangun dan berpengaruh positif.

Selain itu, masyarakat juga berperan penting dalam hal upaya pencegahan pornografi. Di mana masyarakat bisa bekerja sama dengan pemerintah supaya melaksanakan kegiatan sosialisasi mengenai pornografi dan memblokir situs-situs porno, iklan, dan film yang merangsang nafsu seksual (Djamarah 2005, 7). Menurut Elly Risman seorang Psikolog dari Yayasan Kita dan Buah Hati (YKBH), ia menuturkan sesungguhnya sekolah mempunyai peran penting untuk mencegah penyebaran pornografi dan guru dapat melakukan hal-hal untuk mencegah pornografi yaitu: Pertama, Memberikan pengetahuan dan mengingatkan tentang bahaya pornografi yang bisa merusak otak. Kedua, Guru menjadi teladan bagi peserta didik dan tidak memberi contoh yang bisa mengarahkan siswa untuk menyukai pornografi. Ketiga, Guru yang mengajar mata pelajaran teknologi informasi (TI) harus bisa mengarahkan siswa untuk menggunakan TI dengan baik dan benar. Keempat, Pada saat mengerjakan tugas dengan menggunakan internet guru harus mengingatkan untuk menghindari gambar-gambar yang berbau pornografi. Kelima, Fasilitas internet yang ada di sekolah haruslah diperiksa secara rutin untuk mengetahui apakah ada konten pornografi yang di unduh oleh guru ataupun murid. Keenam, Sekolah harus membuat peraturan mengenai penggunaan gadget, dan guru wajib mengingatkan bahwa penggunaan gadget berlebihan bisa membuat siswa tidak konsentrasi mengerjakan tugas. Ketujuh, Sekolah hendaknya bekerja sama dengan orang tua siswa dalam mencegah pornografi. Kedelapan, Sekolah harus melakukan pengecekan bersama tingkat kecanduan anak apakah main-main atau kecanduan. Kesembilan, Melakukan pengawasan terhadap fasilitas dan kegiatan sekolah yang 
bisa mempunyai peluang untuk siswa mengakses pornografi. Kesepuluh, Jika memang ada siswa yang diketahui kecanduang dengan pornografi, sekolah harus menjaga identitas siswa tersebut dan melakukan pertemuan dengan orang tua siswa (Rubiyantoro 2016).

Selain itu ada peraturan hukum Republik Indonesia Nomor 44 Tahun 2008 yang mengatur tentang pornografi. Di dalam undang-undang ini ditetapkan semua yang berkaitan dengan pornografi. Pada bab I memuat tentang ketentuan umum tentang pornografi dari pasal 1sampai pasal 3, selanjutnya pada bab II membahas mengenai pembatasan dan penetapan tentang pornografi pada pasal 4 sampai pada pasal 14. Setelah itu pada bab III membahas mengenai perlindungan anak dari pornografi dari pasal 15 sampai pasal 16, kemudian pada bab IV di bahas mengenai pencegahan pornografi dari pasal 17 sampai pasal 22. Pada bab V menjelaskan perihal penyidikan, pendakwaan, dan penyelidikan di sidang pengadilan, dari pasal 23 sampai pasal 27 , selanjutnya pada bab VI membahas mengenai pemusnahan pasal 28. Pada bab VII membahas tentang ketentuan pidana di pasal 29 sampai pasal 41, dan pada bab VIII membahas mengenai ketentuan penutup dari pasal 42 sampai pasal 45 (Tim BIP 2017, 2-14). 


\section{KESIMPULAN}

Pornografi adalah sebuah produk audio-visual, gambar ataupun tulisan yang bisa merancang nafsu berahi seksual seseorang yang membaca ataupun menontonnya. Pertumbuhan pornografi di lingkungan masyarakat dapat dibagi menjadi lima jenis pornografi, yaitu bahan kekerasan seksual, bahan tanpa kekerasan yang mewakili degradasi, dominasi, subordinasi atau penghinaan, bahan tanpa kekerasan dan ketelanjangan kekanak-kanakan. Menurut pandangan Kristen pornografi Menggambarkan Seks dalam Cara Berdosa, Merendahkan Martabat Manusia, menghancurkan komitmen perkawinan, dan Menanamkan Hawa Nafsu dan Perzinahan.

Penyebab kecanduan pornografi karena ada faktor dari dalam diri dan dari luar seperti lingkungan. Faktor dari dalam diri adalah keingintahuan, minat dalam menonton pameran porno melalui jaringan internet dan kebutuhan seksual yang hebat. Sementara faktor dari luar adalah parenting orang tua, pengaruh lingkungan, pengaruh teman dan teknologi. Pornografi memiliki dampak negatif pada remaja karena menyebabkan ketagihan, merusak otak, keinginan untuk mencoba, meniru dan memulai tindakan seksual.

Karakteristik kecanduan tayangan pornografi di antaranya adalah sering terlihat gugup jika seseorang meminta untuk berkomunikasi, langsung menghindari kontak visual. Individu tersebut tidak memiliki hasrat aktivitas, pencapaian penurunan. Malas, kurangnya minat untuk melatih diri belajar dan tidak mau bergaul dan susah untuk konsentrasi. Terikat dengan gadgetnya, dan lebih senang menyendiri, terutama di kamarnya sendiri.

Pendidikan Agama Kristen merupakan sebuah proses bimbingan dan pengkajian berlandaskan Alkitab, berpaut kepada Kristus dan berserah hanya kepada kekuatan Roh Kudus yang memandu setiap orang di semua tingkat iman. Peran Alkitab juga bekerja untuk menerangi (iluminasi) guru dan siswa untuk menangani semua kegiatan pembelajaran dan meningkatkan spiritualitas. Namun guru PAK sebagai pribadi yang dipercayakan oleh Tuhan untuk melaksanakan pengajaran dan pendidikan berdasarkan dengan karunia yang telah diberikan kepadanya, juga harus bergantung kepada Firman Allah. Sesungguhnya peran guru pendidikan Kristen tidak hanya memberikan bimbingan dan pengajaran di bidang pendidikan Kristen kepada siswa, tujuan yang ingin memiliki guru harus mengembangkan dan mengembangkan iman, sikap dan tindakan sesuai dengan kesaksian di Alkitab dan diterapkan dalam kehidupan siswa sehari-hari. Upaya pencegahan pornografi bisa di mulai dari orang tua dalam mendidik remaja. Orang tua harus meluangkan waktu sebanyak-banyaknya dengan remaja supaya mereka merasa di perhatikan. Masyarakat juga berperan penting dalam hal upaya pencegahan pornografi, masyarakat bisa bekerja sama dengan pemerintah supaya melaksanakan kegiatan sosialisasi mengenai pornografi dan memblokir situs-situs porno, iklan, dan film yang merangsang nafsu seksual. 


\section{REFERENSI}

Arifianto, Yonatan Alex. 2020. "Pentingnya Pendidikan Kristen Dalam Membangun Kerohanian Keluarga Di Masa Pandemi Covid-19.” Regula Fidei Jurnal Pendidikan Agama Kristen 5(2).

Arifianto, Yonatan Alex, and Asih sumiwi Rachmani. 2020. "Peran Roh Kudus Dalam Menuntun Orang Percaya Kepada Seluruh Kebenaran Berdasarkan Yohanes 16: 13." Jurnal Diegesis 3(1): 1-12.

Auer, Jim. 2002. Seks Dan Remaja Kristen. Yogyakarta: Penerbit Kanisius.

Danes, Simon, and Christoper Danes. 2000. Masalah-Masalah Moral Sosial Aktual Dalam Perspektif Iman Kristen. Yogyakarta: Penerbit Kanisius.

Denney, Andrew S., and Richard Tewksbury. 2013. "How to Write a Literature Review." Journal of Criminal Justice Education 24(2): 218-34.

Diananda, Amita. 2019. "Psikologi Remaja Dan Permasalahannya." Journal ISTIGHNA 1(1): 116-33.

Djamarah, Syaiful Bahri. 2005. Guru Dan Anak Didik Dalam Interaksi Edukatif. Jakarta: Renika Cipta.

Djubaedah, Neng. 2011. Undang-Undang Nomor 44 Tahun 2008 Tentang Pornografi Perspektif Negara Hukum Berdasarkan Pancasila. Jakarta: Sinar Grafika.

Driyakarya. 1966. Pertjikan Filsafat. Djakarta: PT. Pembangunan.

Fatin Hafizah, and Mohd Shahar. 2018. "Ketagihan Pornografi Rosakkan Otak." BH Online. https://www.bharian.com.my/wanita/keluarga/2018/04/406081/ketagihan-pornografi-rosakkanotak.

Fikri, Ali. 2019. "Pengaruh Globalisasi Dan Era Disrupsi Terhadap Pendidikan Dan Nilai-Nilai Keislaman.” Sukma: Jurnal Pendidikan 3(1): 117-36.

Groome, Thomas H. 2017. Christian Religious Education - Pendidikan Agama Kristen. 6th ed. Jakarta: Gunung Mulia.

Haidar, Galih, and Nurliana Cipta Apsari. 2020. "Pornografi Pada Kalangan Remaja." Prosiding Penelitian dan Pengabdian kepada Masyarakat 7(1): 136.

Homrinhausen, E.G. 2013. I Pendidikan Agama Kristen. Jakarta: BPK Gunung Mulia.

Intarti, Esther Rela. 2016. "Peran Guru Pendidikan Agama Kristen Sebagai Motivator." Regula Fidei 1(2): 28-40.

Irawan, Toni. 2020. "Pornografi Ditinjau Dari Perspektif Etika Kristen.” LOGIA: Jurnal Teologi Pentakosta 1(2): 87-109. 
K, Rajana. 2017. “Angka Kehamilan Remaja Kalteng Tinggi, Apa Langkah Menteri PPPA?” Liputan6. https://www.liputan6.com/regional/read/3170979/angka-kehamilan-remaja-kaltengtinggi-apa-langkah-menteri-pppa.

Kastilong, Rafel. 2019. "Bahaya Pornografi Yang Merusak Otak." kompasiana.com. https://www.kompasiana.com/rafelkastilong3190/5d136ec50d823004a160ab62/bahayapornografi-yang-merusak-otak (February 12, 2020).

KEMENTERIAN, PEMBERDAYAAN PEREMPUAN DAN PERLINDUNGAN ANAK, and REPUBLIK INDONESIA. 2016. "SOSIALISASI UNDANG-UNDANG NOMOR 44 TAHUN 2008 TENTANG PORNOGRAFI DI LINGKUNGAN PENDIDIKAN." PUBLIKASI DAN MEDIA KEMENTERIAN PEMBERDAYAAN PEREMPUAN DAN PERLINDUNGAN ANAK. https://www.kemenpppa.go.id/index.php/page/read/29/1284/sosialisasi-undang-undangnomor-44-tahun-2008-tentang-pornografi-di-lingkungan-pendidikan (February 12, 2020).

Kusrahmadi, Sigit Dwi. 2007. "Sumbangan Pendidikan Kristen Dalam Mewujudkan Bangsa." Skripsi P. Gsd. Site Universitas Negeri Yogyakarta: 5.

Lestari, Reka Meilda, Sri Handayani Hanum, and Heni Nopianti. 2016. "Problema Kehidupan Berkeluarga Pasangan Suami Istri Kawin Muda (Studi Kasus: Desa Sri Kunciri Kecamatan Pondok Kelapa, Kabupaten Bengkulu Tengah).” Jurnal Sosiologi Nusantara 2(2): 82-93.

"Miris! Indonesia Jadi Juara Negara Pengakses Situs Konten Dewasa." 2018. Jambiindependent. https://www.jambi-independent.co.id/read/2018/03/03/20086/miris-indonesia-jadijuara-negara-pengakses-situs-konten-dewasa (February 12, 2020).

Mulyono, Bambang. 1986. Kenakalan Remaja. Yogyakarta: Andi Offset.

Novita, Eryanti. 2018. "Faktor-Faktor Yang Mempengaruhi Kebiasaan Menonton Film Porno Pada Remaja." Anthropos: Jurnal Antropologi Sosial dan Budaya (Journal of Social and Cultural Anthropology) 4(1): 31.

Novita, Mila. 2019. "4 Dampak Pornografi Pada Anak, Kerusakan Otak Dan Kecanduan." TEMPO.CO. https://gaya.tempo.co/read/1219602/4-dampak-pornografi-pada-anak-kerusakanotak-dan-kecanduan (February 12, 2020).

ORG, SEMAI. 2015. "Bahaya Pornografi: Merusak Otak." Youtube. https://www.youtube.com/watch?v=O9rMmjVa5QI. (February 12, 2020).

Paul Lilik Kristianto. 2006. Prinsip Dan Praktik Pendidikan Agama Kristen Penuntun Bagi Mahasiswa Theologi Dan Pak Pelayanan Gereja Guru Agama Dan Keluarga Kristen. Yogyakarta: Andi Offset.

Pazmino, Robert W. 2012. Fondasi Pendidikan Kristen. Jakarta: BPK. Gunung Mulia.

Prayitno. 2009. Dasar Teori Dan Praktis Pendidikan. Jakarta: Grasindo.

Rubiyantoro, Yohan. 2016. "Sepuluh Hal Yang Dapat Dilakukan Sekolah Untuk Mencegah Pornografi." Kementerian Pendidikan dan kebudayaan. https://sahabatkeluarga.kemdikbud.go.id/laman/index.php?r=tpost/xview\&id=3189.

Sardiman. 2007. Interaksi Dan Motivasi Belajar-Mengajar. Jakarta: Raja Grafindo Persada. 
Sardjito, Humas. 2019. "Dampak Pornografi Bagi Kesehatan Pada Remaja, Apakah Berbahaya?" RSUP Dr. Sardjito. https://sardjito.co.id/2019/10/30/dampak-pornografi-bagikesehatan-pada-remaja-apakah-berbahaya/ (February 12, 2020).

Sebayang, Wellina, Destyna Yohana Gultom, and Eva Royani Sidabutar. 2018. Perilaku Seksual Remaja. Yogyakarta: Deepublish.

Sipayung, Hendra, and Marselinus Heriteluna. 2017. "Faktor-Faktor Yang Mempengaruhi Perkawinan Dini Di Murung Raya Kalimantan Tengah.” In Jurnal Forum Kesehatan, , 27-35.

Soebagijo, Azimah. 2008. Pornograpi Dilarang Tapi Dicari. Jakarta: Gema Insani.

Solikhin, Nur. 2018. Rumahku Madrasahku,. Yogyakarta: Laksana.

Syafriadi, Andi. 2020. "Berikut Berbagai Alasan Mengapa Industri Film Dewasa Tak Pernah Padam." Akurat.co. https://akurat.co/ekonomi/id-951964-read-berikut-berbagai-alasanmengapa-industri-film-dewasa-tak-pernah-padam.

Tim BIP. 2017. Undang-Undang Pornografi. Jakarta: Bhuana Ilmu Populer.

Waruwu, Mesirawati, Yonatan Alex Arifianto, and Aji Suseno. 2020. "Peran Pendidikan Etika Kristen Dalam Media Sosial Di Era Disrupsi.” JUPAK: Jurnal Pendidikan Agama Kristen 1(1): $38-46$.

Widarti, Catur. 2008a. "Faktor-Faktor Yang Mempengaruhi Efek Paparan Pornografi Pada Remaja Sekolah Menengah Pertama Negeri (SMPN) Di Kota Depok Tahun 2008.”

. 2008b. "Faktor-Faktor Yang Mempengaruhi Efek Paparan Pornografi Pada Remaja Sekolah Menengah Pertama Negeri Di Kota Depok Tahun 2008."

Yusnadewi, Suzy. 2013. Kiat Menjadi Orang Tua Hebat Dengan Metode Mindfulness,. Jakarta: PT Elex Media Komtindo Kelompok Gramedia.

Zaluchu, Sonny Eli. 2020. "Strategi Penelitian Kualitatif Dan Kuantitatif Di Dalam Penelitian Agama.” Evangelikal: Jurnal Teologi Injili dan Pembinaan Warga Jemaat 4(1): 28-38. 